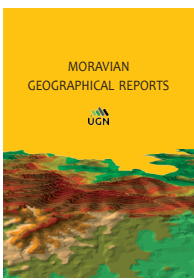

MORAVIAN GEOGRAPHICAL REPORTS

The Czech Academy of Sciences, Institute of Geonics

journal homepage: http:/www.geonika.cz/mgr.html

doi: https://doi.org/10.2478/mgr-2021-0007

\title{
The influence of the Covid-19 pandemic on Czech-Polish cross-border cooperation: From debordering to re-bordering?
}

\author{
Hynek BÖHM ${ }^{\mathrm{a}, \mathrm{b}}$ *
}

\begin{abstract}
:
The COVID-19 pandemic brought many changes to social behaviours in Europe. One of its major consequences was the temporary closure of borders, which was introduced as a measure to prevent the uncontrolled pandemic spreading and involved internal Schengen borders. This has had a major impact in the way in which cross-border cooperation has been conducted in Europe, including the Czech-Polish borderland, as it dramatically restrained all flows across borders. In this paper, we evaluate the impact of the pandemic on five roles of cross-border cooperation: 1) as a multi-level governance form; 2) as a regional development tool; 3) as a para-diplomacy form; 4) as a post-conflict reconciliation tool; and 5) as Europe-building. We argue that the impacts of the pandemic complicated regional development and the Europe-building role of cross-border cooperation in the Czech-Polish borderland. The article envisages re-bordering processes also in the Czech-Polish borderland, but with important exceptions in the regions with a high level of cross-border integration, mainly in the Euroregion Těšinské Slezsko/Śląsk Cieszyński. The paper also calls for the elaboration of the guidelines for possible repeated (Schengen) border closures and proposes modifications of the INTERREG microprojects schemes, to keep them attractive also in times of expected cuts in public finances.
\end{abstract}

Key words: COVID-19 pandemic; re-bordering; cross-border cooperation and its roles; Czech-Polish border; Poland; Czech Republic

Article history: Received 10 July 2020, Accepted 18 January 2021, Published 30 June 2021

\section{Introduction}

The Schengen space and the narrative of free border crossings constitute cornerstones of European integration (Scott, 2016). The developed cross-border cooperation $(\mathrm{CBC})$ is an integral part of this story. A substantial part of Europeans (used to) cross national borders on a daily or weekly basis for education, work or leisure (ESPON, 2018; Jaansoo, 2019) and contributed thus to de-territorialism (Medeiros et al., 2020). The decreasing importance of national borders, studied as debordering, created a mainstream of border scholarship (Brunet-Jailly and Wassenberg, 2020).

This story started to be harpooned by growing Euroscepticism, which had Brexit as its main consequence so far (Riedel, 2018). Migration crises and the related increase of populism based on identarian/localism discourses in the world and European politics brought along observable rebordering (Wassenberg, 2020). Despite some European Union (EU) Member States introducing temporary borderchecks as a reaction to migration waves and terrorism acts in 2015, the borders were generally open until March 2020. Then the epidemic danger affected Schengen space and imposed physical barriers on EU internal borders, which dramatically lowered the intensities of cross-border flows.

The border closure of March 2020 was imposed as an immediate, yet doubtful (Espinoza, Castillo-Chavez and Perrings, 2020) reaction to the COVID-19 pandemic, as a universal panacea for the EU and much of the world. It reminds one very much of the role of borders as a barrier to protect from a neighbour - implicitly suspicious to be the infected one. It also constitutes an example of applying the "us and them" logic (van Houtum and Van Der Velde, 2004), a major mental CBC obstacle, which can sometimes be more severe than the 'hard' versions (Havlíček, Jeřábek and Dokoupil, 2018). Given the relatively recent outbreak of this health crisis, there have been few robust research projects finished so far. We can work, however, with the first reactions in the form of scientific articles (Medeiros et al., 2020; Opiłowska, 2020), blogs and non-peer-

\footnotetext{
${ }^{\text {a }}$ Institute of Political and Administrative Sciences, University of Opole, Opole, Poland (*corresponding author: H. Böhm, e-mail: hynek.bohm@uni.opole.pl)

${ }^{\mathrm{b}}$ Department of Geography, Faculty of Science, Humanities and Education, Technical University of Liberec, Liberec, Czech Republic
} 
reviewed papers (Klatt, 2020; Jańczak, 2020; Berrod and Bruyas, 2020; Böhm, 2020). They observed massive rebordering tendencies, as most of the measures based on social distancing were introduced on a strictly national basis and contradicted steps desired by the European institutions (Brunet-Jailly and Vannet, 2020). These restrictions made $\mathrm{CBC}$ very difficult to implement. Moreover, the pandemic has introduced a new level of uncertainty in all international including cross-border - affairs and led many to question whether citizens will be able to continue enjoying the freedom of movement once the crisis is over (Calzada, 2020). Nevertheless, the pandemic also pointed to high levels of cross-border integration in some European cross-border regions, where the locals voiced themselves loudly against the closed borders (Opiłowska, 2020).

National borders were closed in many countries of the world. The border closures caused by the pandemic occurred mostly with the support of most of the public in the EU Member States (Euronews, 2020). Most European citizens have accepted the necessity to temporarily close the border due to public health reasons. In some EU Member States, however, citizens would agree on border closures also for midand long-term horizons. The public opinion polls conducted in the Czech Republic during the first pandemic wave revealed that about one third of the Czech population would agree to having the border closed for a longer period and 5\% of them even forever (National Pandemic Alarm, 2020). This implies a fertile ground for re-bordering.

This article attempts to outline the principal influences of the COVID-19 pandemic on the development of CBC implemented in the Czech-Polish borderland, where the border was closed from March to June 2020. It tries to identify whether we can expect re-bordering trends in this territory in a long-term perspective. We also examine whether the concept of the five roles of cross-border cooperation (explained later) can be used to study the impacts of the pandemic on cooperation.

We worked with the hypothesis that these influences will appear to be negative and will substantially complicate Czech-Polish CBC. These prospects might result in studying re-bordering rather than de-bordering of this territory in the near future. This could bring a relatively new view on Czech-Polish CBC, as its scholarship has up to now predominantly focused on debordering (Pásztó et al., 2019; Böhm and Drápela, 2017; Böhm and Opioła, 2019). Scholars have identified a very high number of local cross-border connections between municipalities (Furmankiewicz, 2007). Dołzbłasz (2015, 2017), and Vaishar et al. (2013) have underlined the importance of cross-border tourism. Divided cities, mainly Cieszyn - Český Těšín, play an important integrating role in Czech-Polish $\mathrm{CBC}$ and its scholarship (Jańczak, 2014; Boháč, 2017; Zenderowski and Krycki, 2014).

This article is organised as follows: the first section provides an overview of the main research directions in border studies. While it identifies debordering as the current dominant part of the border studies research agenda, it dedicates special attention to the re-bordering processes in Schengen space. The next section outlines the methodology and the main materials which were analysed in the article. The fourth section deals with the recorded and possible impacts of the pandemic on Czech-Polish CBC on the basis of the latest texts covering other border contexts in the EU, unpublished reports and data, and presents an expected impact of the pandemicrelated border closures on five different CBC roles - these roles are specified in subsection 2.1. The final section draws conclusions, which also advise on potential directions for further research of the Czech-Polish CBC.

\section{References to study the impact of the pandemic on cross-border cooperation}

The principle theoretical approaches to the study of CBC are outlined here. It introduces border studies as a specific intersection of several social sciences. Then it points at an expected shape of conceptual approaches to study borders, co-evidenced also by the pandemic: we could probably expect more studies of re-bordering in the near future. This contrasts to the border studies "mainstream", which has accented debordering/de-territorialism research endeavours.

\subsection{Border studies as a specific intersection of several social sciences}

We can argue that border scholarship focuses on frontiers and boundaries. The decreasing importance of borders is connected to the process of frontierisation, as it prompts the erosion of boundaries, which can be described as "sharply drawn lines that mark the limits of authority and ownership (...), marked, and managed, sometimes loosely and sometimes strictly in accordance with the various and changing purposes of the adjoining states" (Custred, 2011, p. 265). Limited border controls and the declining importance of borders lead to their increasing porosity, more intense interaction and consequently the emergence or reconstruction of the elements of a frontier (Jańczak, 2014; Böhm, 2019). Frontierisation applies to social, economic and political elements referring chiefly to borderland communities (O'Dowd and Wilson, 2002). As a result, frontiers are "zones of varying width, either political or cultural in nature" (Custred, 2011, p. 265). Assimilation or even expansion by one of the dominating parties is becoming a common frontier occurrence (Walters, 2004; Jańczak, 2014). A boundary is a mainly legal concept which separates state structures (O'Dowd and Wilson, 2002). The boundary not only separates from what is outside but at the same time bounds what is inside (Kristof, 1959).

We should not forget that these two processes unfold in a context of historical legacy, as well as in the actual border reality (Jańczak, 2014). Keeping in mind the historical origin of borders, both boundarisation and frontierisation reveal their two-fold nature. On the one hand, they reflect ongoing existing processes, therefore they constitute an element of a real policy specific to a time and place. On the other hand, they are set in a historical context where, until recently, borders served a different purpose, had a different form and ran along different lines. Both processes, however, debordering analysing frontierisation and re-bordering studying boundarisation, create the very core of border studies.

Brunet-Jailly (2005) proposed a theory of borderland studies, which is based upon the interplay of the following four analytical lenses: (1) market forces and trade flows; (2) policy activities of multiple levels of governments on adjacent borders; (3) the particular political clout of borderland communities; and (4) the specific culture of borderland communities.

According to this theory, if each of those analytical lenses complements/enhances one another, it enables an emergence of the culturally emerging and integrating borderland region. Brunet-Jailly's concept understands border studies as a specific interdisciplinary field, where geography meets 
sociology, political sciences, cultural sciences, legal and administrative sciences, economics and history (Beck, 2018). Decoville (2013) identified structural, functional, ideational and institutional functions of CBC. Böhm (2020) follows the same interdisciplinary logic and argues that the $\mathrm{CBC}$ has five principal roles:

1. The role of multi-level governance of the territory: entities responsible for the management of $\mathrm{CBC}$ are composed of members, who represent various levels of public administration, most often municipalities and regions. Most of the cross-border groupings in the EU have the form of an Euroregion, while other legal forms such as European Groupings of Territorial Cooperation (EGTC) are on the rise in the EU (Dura et al., 2019). These groupings generally follow multi-level governance principles (Hooghe and Marks, 1993) in practice;

2. A regional development role: $\mathrm{CBC}$ can benefit from mutual cross-border complementarities. The existence of the Schengen space and European single market led to an increase in cross-border employment in the EU, as well as in the Czech-Polish borderland (Böhm and Opioła, 2019), and the growth of cross-border public services, which are implemented in areas such as transport, leisure or healthcare (ESPON, 2018). Sometimes, the existence of these services can lead to functional cross-border regions - for example the cross-border labour market region around Luxembourg, where massive cross-border flows take place, which required equal policy measures (Decoville et al., 2013);

3. The role of a para-diplomacy tool: for many municipalities, mainly smaller ones, the $\mathrm{CBC}$ is their only engagement in international cooperation (Klatt and Wassenberg, 2017; Duchacek, 1990);

4. The role in post-conflict reconciliation: many of the border regions in the EU are places of former conflicts, as is also the case in the east of the Czech-Polish border (Böhm and Drápela, 2017). The CBC is a tool which helps to mitigate the consequences of those conflicts, which has been demonstrated on the French-German or GermanDutch border (Klatt and Wassenberg, 2017); and

5. The previous four roles represent functions of the CBC. All of them exist to mitigate the barrier effect of the national border. They support the principle of mutual interdependence of neighbours and comply with the principal ideas of European integration (e.g. Scott, 2016). Hence, we can conclude that the CBC is a European integration element because it contributes to political and economic as well as cultural integration - see Figure 1.

The five above-mentioned roles cover functional, ideational, structural and institutional dimensions of CBC and reflect the interdisciplinarity of border studies. Hence, we decided to structure part of our research according to these roles: see Section 3

In this article, we study the EU Schengen Area internal border between the Czech Republic and Poland. The question of EU internal borders is fundamental, as it reflects the ambiguity of European construction and its neither federal nor confederate nature. We no longer refer to "national borders" but to "internal borders", often without referring to the EU. This means, on the one hand, that the internal borders of the EU are special ones, but, on the other hand, that the border remains between the Member States or at least that it may be called upon to reappear (Bouveresse, 2020).

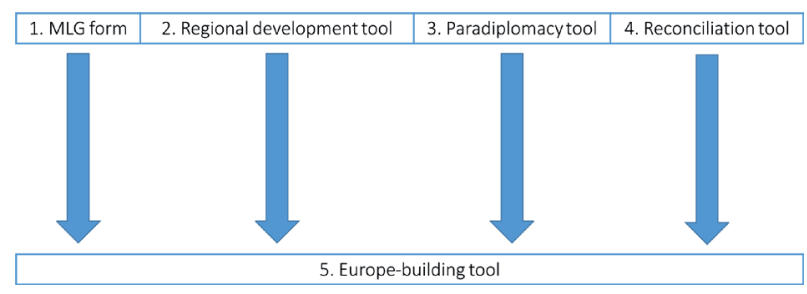

Fig. 1: The five roles of cross border cooperation Source: author's elaboration based on Böhm (2020)

\subsection{Researching debordering}

Before the refugee crisis of 2015, most of the scholars focusing on $\mathrm{CBC}$ studied debordering. They claimed that multi-level governance, EU regional cohesion policies especially the INTERREG programme, the Europe of Regions discourse and an increase of paradiplomatic activities of sub-nation state authorities - supported a consensus on rescaling Europe with an increasing influence of regional and local actors from a cross-border perspective (Klatt, 2018; Keating, 1998; Scott, 1999; Telo, 2007; Warleigh-Lack and Rosamond, 2011; Hooghe and Marks, 1993). The CBC, which is based on mutual interdependence, is associated, then, with the tangible successes of the European integration process (Scott, 2016).

In the last 20 years, the number of CBC structures has, especially with respect to the INTERREG programme, exploded in Europe (Zumbusch and Scherer, 2019). The proliferation of CBC and related discourses in political science are linked with the following international tendencies that have affected the status of national borders in recent years, as well as enhanced integration processes across these borders by various mechanisms (e.g. Perkmann, 2002; Scott, 1999):

- Globalisation and continuous internationalisation, Europeanisation as a top-down stimulus;

- Regionalisation and corresponding multi-level governance approaches as bottom-up emerging drivers;

- A changed understanding of borders from detrimental limitations to a source of opportunities;

- Increasing orientation from a territorial logic of space to functional spaces; and

- The opening of government and resultant governance processes in multi-actor, multinational constellations (Zumbusch and Scherer, 2019).

The Covid-19 pandemic has challenged all the abovementioned cornerstones of debordering research. The pandemic showed that despite national borders which were once thought to be a feature of Europe's past, the pandemic has underlined how resilient and meaningful they continue to be (Castan Pinos and Radil, 2020).

\subsection{Researching re-bordering}

The systemic and everywhere-present closures of national borders during the Covid-19 pandemic introduced the largest re-bordering in the history of European integration. According to Falludi (2018), territorialism, understood as a collection of states, currently shapes national identities and perceptions of the world, which remains largely Westphalian, and the pandemic showed us that nation states continue to be the basic "social containers" which define the world system (Rufi et al., 2020) - even in the EU. Medeiros et al. (2020), in one of the first responses of border scholars to the new reality of Covid-19, related re-bordering to the term 'Covid-fencing', explained as the systematic closing 
of national borders to the circulation of people. This Covidfencing indicates that these territorialism perceptions enjoy an overwhelming acceptance, despite the authors' denial of the fact that the issue is black or white, and that they understand $\mathrm{CBC}$ to be a cement of European integration.

It was the 2015 refugee crisis, however, which led to a questioning of both the functions of borders in controlling migration, as well as European integration as a whole. The ideal of a "Europe without borders" was questioned because both the Schengen agreement and the Dublin convention were unable to deal with this crisis (BrunetJailly and Wassenberg, 2020). According to studies of the French-Italian border, the impact of the 2015-crisis related border checks on inhabitants of this region was rather symbolic than factual, as the checks concentrated on thirdcountry nationals and left the majority of border crossings unaffected (Casella Colombeau, 2020). It would be incorrect or at least incomplete, however, to blame mere refugee crises. Svensson (2020, p. 2) points at the early 2000s, when global and regional geopolitical events had encouraged processes of re-bordering: "The 2001 terrorist attacks stood at the beginning of a period of securitisation with enhanced border controls ... Moreover, the Arab Spring has started a domino process of instability in the European neighbourhood, which led to the of unregulated migration into and within the EU".

Before the Covid-19 pandemic or the 2015 refugee crisis, moreover, Scuzzarello and Kinvall (2012) claimed that temporary closures of borders in France and in Denmark aimed to show how some European nation-states attempted to reclaim their power of border control by tweaking the Schengen agreement. These events are not only examples of how countries manage inflow and outflow of people, but they are trying to reinstate narrative identity boundaries around the French and the Danish people by controlling the border. Scuzzarello and Kinvall (2012, p. 90) advocated that “... physical borders find legitimacy in boundaries, i.e. narratives that conceptually separate groups and territories", which they illustrated by means of an analysis of local media in both countries.

The concept of unfamiliarity (van der Velde and Spierings, 2010) could help to understand the increase of re-bordering approaches, as the pandemic made the closed borders an immobility zone within a bandwidth of unfamiliarity much larger - see Figure 2.
Klatt (2018, p. 572) claims that despite the fact that

“...European integration in principle has been a story of debordering, border regions demonstrate that borders have been quite persistent and have continued to be the physical expression of state sovereignty, reflecting the complicated reality of the EC/EU of shared sovereignty between member states and supranational institutions. Furthermore, debordering of the EU has been challenged by competing political elites, who construct otherness to demonstrate efficiency and strength of dealing with alleged threats to security."

Despite the effect of the refugee crisis of 2015 which led to re-bordering processes such as the introduction of border controls or a militarisation of the border (Klatt, 2018), it was still an issue of a low number of borders - which contrasts to the collapse of Schengen system in the pandemic period, when just a part of German-Dutch border remained open. Given that the 2020 Covid-19 pandemic complicated border crossing and restrained cross-border flows, we expect that the pandemic and post-pandemic period might illuminate the study of processes of re-bordering.

\section{Materials and methods}

The work was organised in three steps: 1) desk research; 2) a focus group with the stakeholders of the Czech-Polish CBC; and 3) semi-structured interviews with an extended group of those stakeholders based on a rating scale, which helped to assess the importance of pandemic-related impacts on the $\mathrm{CBC}$.

In the first desk-research phase, we benefitted from the fact that border scholars and CBC practitioners reacted to the pandemic and used multiple channels to do so. A content analysis (see Krippendorf, 2004; Neuendorf, 2017) of those works and presentations at topical e-conferences was conducted. As it was not possible to follow all relevant texts (often published without peer-review in thematic blogs) and e-events, the selection of sources may not have been exhaustive. We worked exclusively with papers and e-events held in English, Polish and Czech. With one exception from the Canadian-US border (Brunet-Jailly and Vannet, 2020), we focused on the European context (basing our work on the conference panel organised by Adam Mickiewicz University in Poznań on 21 May 2020, and the e-meeting "Cross-border cooperation in the age of pandemic", organised by the Association of European Border Regions on 5 June, 2020) ${ }^{1}$.

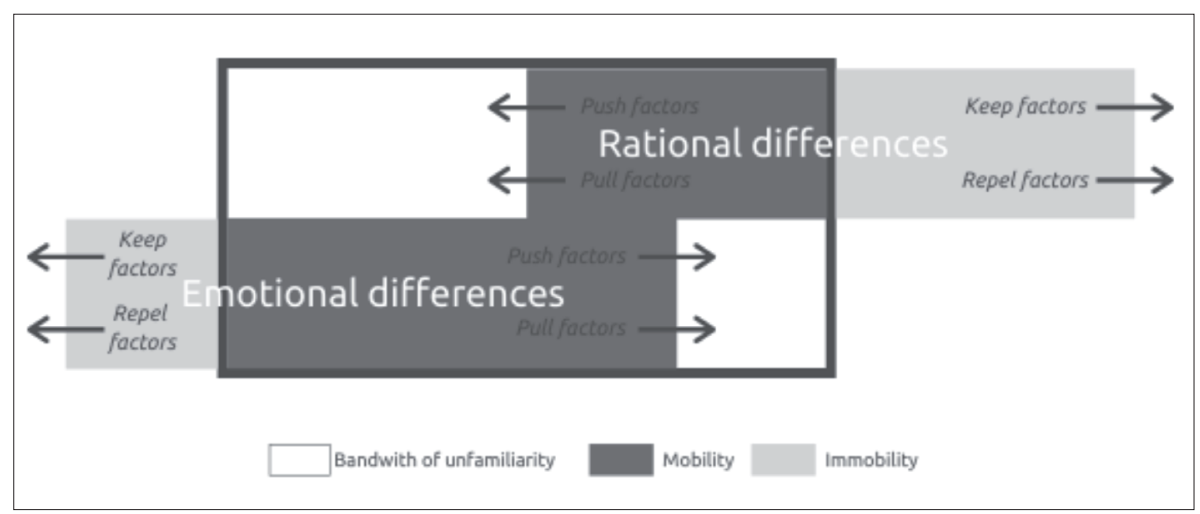

Fig. 2: Bandwidth of unfamiliarity

Source: author's elaboration based on Van der Velde and Spierings (2010)

\footnotetext{
1 The record of these debates can be found here: https://www.facebook.com/watch/live/?v=246409096581222andref=watch permalink and: https://www.facebook.com/AEBR.AGEG.ARFE/videos/2624424017826813
} 
We also analysed the adopted anti-epidemic measures at the level of the Czech and Polish governments. We studied the decrees and other official documents published by these governments, representatives of local and regional actors, and commentaries of the media and other relevant actors in those decisions.

In the second phase we organised a focus group gathering stakeholders of Czech-Polish CBC, which was for the needs of this article structured around impacts of the pandemic on the above-mentioned five $\mathrm{CBC}$ roles $^{2}$. We asked those stakeholders following questions:

- What is the impact of the pandemic on the role of crossborder cooperation as a tool of multi-level governance of the territory?

- What is the impact of the pandemic on the role of crossborder cooperation as a tool of regional development of the territory?

- What is the impact of the pandemic on the role of crossborder cooperation as a para-diplomacy form?

- What is the impact of the pandemic on the role of crossborder cooperation as a reconciliation tool? and

- What is the impact of pandemic on the role of crossborder cooperation as a Europe- building tool?

The invited CBC stakeholders represented secretariats of the selected four Czech-Polish Euroregions, with a high or at least average level of cross-border integration according to Pásztó et al. (2019): Euroregion Těšínské Slezsko/Śląsk Cieszyński, Euroregion Silesia, Euroregion Glacensis and Euroregion Nisa/Nysa/Neisse. We also profited from the presence of representatives of the Pedagogic Centre for Polish Minority Schools in the Czech Republic because this subject has actively contributed to many cross-border initiatives along the Czech-Polish border. We also invited representatives of both European Groupings of Territorial Cooperation from the Czech-Polish borderland, the EGTCs TRITIA and NOVUM, but they could not participate. Their opinions were obtained in the third phase, however.

The outcomes of the first two phases offered some preliminary results, which helped to identify the following group of six principal expected impacts of the pandemic on the Czech-Polish CBC:
1. The advent of unilateralism: the central state returned as a key (and only) actor, who bypassed existing crossborder governance structures, limited cross-border flows and substantially complicated CBC;

2. The limitations of cross-border flows damaged the local economies of the Czech-Polish borderland;

3. Border closures lowered the possibility of mutual crossborder contacts and events;

4. The pandemic contributed to the re-emergence of mutual animosities;

5. The economic crisis would decrease the revenues of local actors, which could limit their ability to conduct CBC; and

6. The implementation of INTERREG-funded projects was substantially complicated and/or disabled.

In the third phase of the research project, we applied a rating scale method, which was intended to rank the impacts and consequences of the closed border on the five CBC roles. A 'five to one' scale was used - where 5 stands for the greatest impact and 1 for the least impact. Despite its limitations (Krosnick and Presser, 2010; Uher, 2018), it was the most "economic" instrument to obtain reliable information in a relatively short time. We used this method in semi-structured interviews with fourteen experts - the same as those involved in the previous phase of the research, plus some new ones representing civic society (for the outcomes see Tab. 1).

\section{Results: Impact of the pandemic and related border closures on Czech-Polish cross-border cooperation}

There are six Euroregions, which have been created in the case study borderland since 1991 - see Figure 3. These regions have an important role in distributing CzechPolish INTERREG funds: a sum of -45.2 million - which is $20 \%$ of the entire programme envelope - was allocated for microprojects in the period 2014-2020, projects which are managed and distributed by Euroregions (INTERREG, 2015). These Euroregions have been the subject of scholarly attention (e.g. Siwek, 2018; Ptáček et al., 2017; Czepil and Opioła, 2013; Drápela and Bašta, 2018;

\section{Consequences of the pandemic/ $\mathrm{CBC}$ roles}

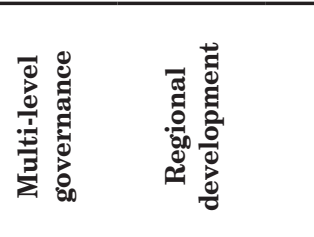

Advent of unilateralism - central state as a key actor
Limitations of cross-border flows damage local economy
Limitation of cross-border events and contacts
Re-emergence of mutual animosities
Decreased revenues of local actors may limit their ability to conduct CBC
Complications for INTERREG programme
Summary

3.1

2.3

2.4

2.4

4.3

2.3

2.8

:

1.6

1.6

2.3

2.3

2.6

3.0

2.4

2.6

2.4

Tab. 1: The mean value of the $N=14$ experts' assessments, rating the effect of the analysed factors on the five roles of $C B C$ on a five-point rating scale, from 1 (lowest impact) to 5 (the highest impact) Source: authors' calculations

\footnotetext{
2 The record of this panel can be found (in Czech) on https://www.youtube.com/watch?v=u7Sdx1TMCe4
} 
Furmankiewicz, Buryło and Dołzbłasz, 2020). One of the recent contributions assessed the cross-border (spatial) continuity on the entire borders using a comparative Euroregional perspective (Pászto et al., 2019). It identified the highest levels of such continuity in the eastern part of the Czech-Polish borderlands (Euroregion Těšínské Slezsko/ Śląsk Cieszyński and Silesia), where no massive population changes were recorded and where the low language barrier does not prevent mutual cooperation (Pásztó et al., 2019; Böhm and Opioła, 2019). The most discontinuous region is Euroregion Praděd/Pradziad, which was influenced by population exchange and its current low population density and rural character (Pásztó et al., 2019).

The pandemic influenced cross-border practices in the entire Czech-Polish borderland, as it closed the mutual border, which was an unprecedented act since both countries joined the Schengen space in 2007. Poland reintroduced border controls at all internal Schengen land, air and sea borders, from 15 March to 12 June 2020. The Czech Republic, which did not have to do it with Poland and Slovakia, as these neighbours did it first, re-introduced its border control at land borders with Germany and Austria and air borders from 14 March to 13 June 2020. Bordercrossing was permitted just for narrowly-specified groups including cross-border commuters, who had their lives complicated by the quarantine obligations - at a limited number of border-crossing points, which made cross-border commuting much longer.

Our research of the impacts of border closures on the CzechPolish CBC revealed six principal impacts: in subsection 4.1 we argue that this border closure was an act of unilateralism, which directly damaged the local economy and led to the lowering of cross-border contacts. It contributed to the rise of mutual animosities, but also to the increased visibility of active cross-border civic society and its responses to the crisis. In subsection 4.2 , we try to assess the pandemic's impacts on the five roles of $\mathrm{CBC}$ and to rank which of those roles were the most affected ones.

\subsection{The impact of border closures on Czech-Polish cross- border cooperation and their consequences}

The desk research and work with the experts revealed six principal impacts and consequences of border closures on the Czech-Polish CBC. They will be presented in the following subsections 4.1.1-4.1.6.

\subsubsection{The advent of unilateralism - the central state returned as a key (and only) actor}

In the beginning of the pandemic in Europe, on 12 March 2020, the French president Macron tried to predict the development of the health crisis: "There will undoubtedly be control measures, border closures, but these measures must be taken as European ones, at the European level, because it's at this level that we've constructed our freedoms and protections" (Berrod and Bruyas, 2020, p. 2).

He was mistaken, as all EU Member States acted without major coordination almost exclusively on the national level. The behaviour of Polish and Czech governments was also an example of such unilateralism at the beginning of the pandemic: the Czech government had its first "pandemic" crisis meeting on 12 March 2020 and accepted nine decrees responding to the pandemic. Five of them limited the free movement of people across the border ${ }^{3}$. These measures were not subject to consultation with the representatives of neighbours, the European Commission, regional and local levels of public administration or other social partners such as entrepreneurs, who employ cross-border commuters. The interviewed experts underlined that both Polish and Czech governments have "bypassed and ignored" or "have not consulted" existing cross-border governance structures. This contributed to the fact that the specificities of border regions were not taken into consideration and the initial measures

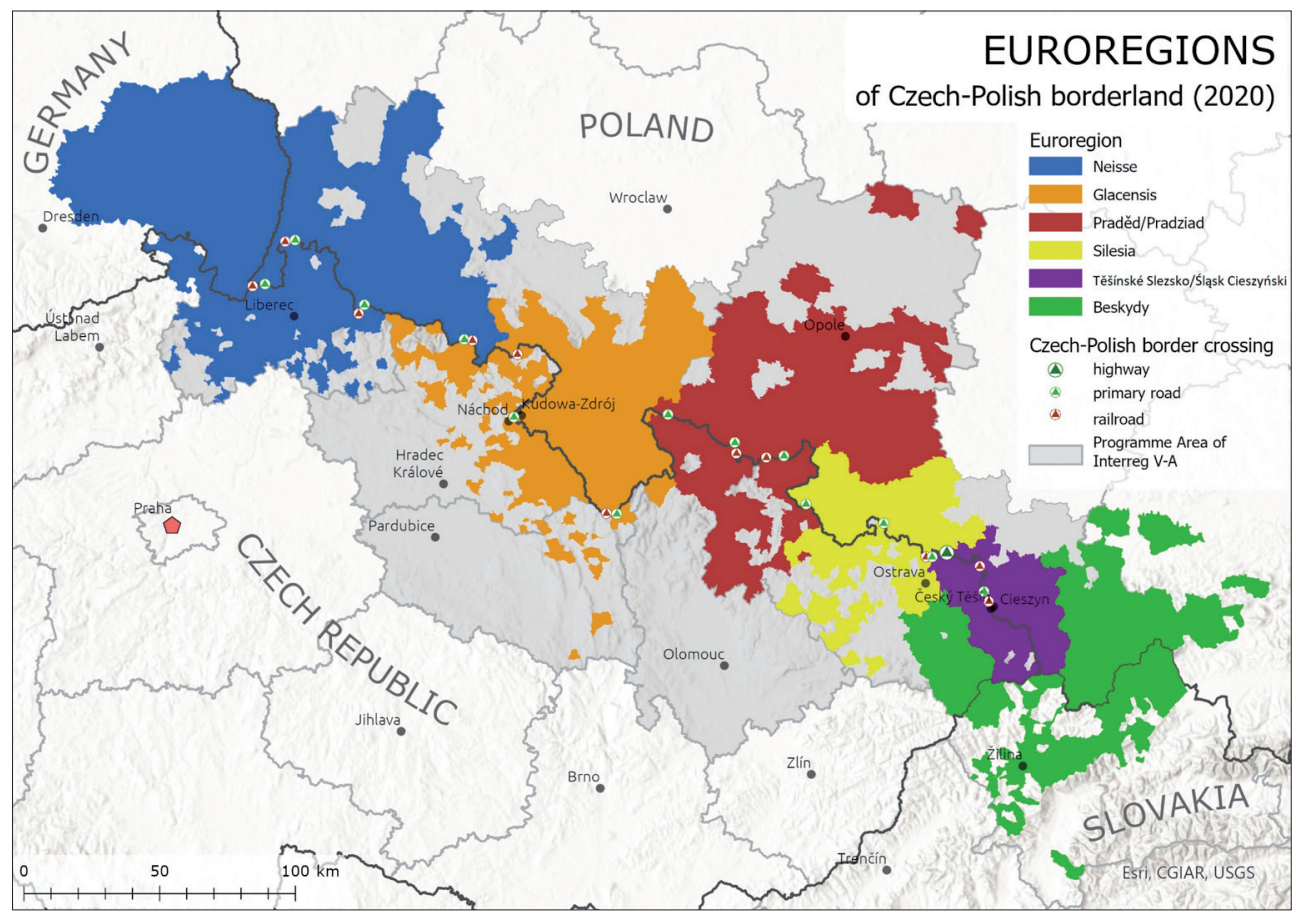

Fig. 3: Euroregions of the Czech-Polish borderland Source: author's elaboration

\footnotetext{
${ }^{3}$ https://www.vlada.cz/cz/epidemie-koronaviru/dulezite-informace/prehled-vladnich-usneseni-od-vyhlaseni-nouzoveho-stavu-180608/\#brezen
} 
created substantial problems for the local economies of the borderland, which is to some limited extent also relying on cross-border flows. A good illustration of the feelings of politicians from a local level was given by Anna Hetman, the mayor of (Polish) Jastrzebie-Zdrój and a member of the Euroregion Těšínské Slezsko/Śląsk Cieszyński board:

“...Hundreds of residents of Jastrzębie-Zdrój, who commuted daily to work in industrial plants and mines in neighbouring Czech towns, lost this opportunity overnight, and lost thus the possibility of earning, often the only family income. I fully understand the extraordinary and unprecedented situation in which we find ourselves and the resulting concern for the best security of our country. However, it must not be at the expense of cross-border commuters, who have to choose between a job in the Czech Republic without a chance to live a normal family life or losing the only family income. Leaving them only one day to make such an important decision is not acceptable. Moreover, in comparison to the locals employed in Poland, who receive social benefits while being on the forced quarantine, those employed in the Czech Republic are left without any financial support" (Hetman, 2020).

Her words underlined that local authorities - mostly in Euroregions - were forced to react to these unilaterally taken decisions and their influence on the group of crossborder commuters to protect their rights, as detailed in the next subsection.

\subsubsection{The limitations of cross-border flows damage local economies of the Czech-Polish borderland}

Before the pandemic started, some 48,000 people were benefitting from the advantages of the Czech-Polish crossborder labour market - mainly Poles, who worked in Czech enterprises (Kasperek and Olszewski, 2020). The pandemic restricted free cross-border flows and complicated the functioning of local economies in the Czech-Polish borderland. This was mainly due to the Polish government, which introduced (27 March, 2020) an obligatory two weeks quarantine for Poles returning home from abroad, which also applied to the cross-border commuters. This led to two principal reactions: one group of Polish cross-border commuters decided to stay at work in the Czech Republic, found accommodation there and was practically separated from their families. The other group decided to stay home and resigned on the whole or part of their income, which on the other hand caused significant difficulties for their Czech employers. The pandemic caused the most substantial problem for the less qualified workforce employed in the manufacturing industry, as these employees are often the only breadwinners of their families (Kasperek and Olszewski, 2020).

Moreover, these cross-border commuters organised demonstrations against the restrictions. They took place mainly in both the Czech and the Polish part of the divided town of Český Těšín/Cieszyn - where the highest levels of mutual interactions are observed (Pászto et al, 2019; Böhm and Opioła, 2019) - and we can even talk about a crossborder functional labour market region. Such reactions were also seen in other places (such as Náchod/Kudowa-Zdrój).

Euroregions where cross-border commuting had been strongly present, started to act as advocates of crossborder commuters. They developed - with the support of other Euroregions - concentrated and partly co-ordinated efforts to change the quarantine obligation. This happened by means of letters to the Polish prime minister (and later to his Czech counterpart), which were supported by the analytical evidence elaborated by the Těšínské Slezsko/Śląsk Cieszyński Euroregion (Kasperek and Olszewski, 2020), providing further reasons to lift the quarantine obligations. Euroregions Těšínské Slezsko/Śląsk Cieszyński and Glacensis (where Poles work in the Škoda Auto factory in Kvasiny) were the most active organisations in the CzechPolish borderland (cf. Böhm and Opioła, 2019).

As mentioned, the quarantine obligation also damaged employers: for example, the Czech textile factory JUTA was not able to manufacture an expected/contracted volume of goods due to the non-availability of the Polish workforce, who preferred to stay home in the obligatory quarantine to take care for their families, despite the employer offering to pay for their accommodation in the Czech Republic (Novinky.cz, 2020). Another practical tangible impact of the pandemic could be seen in the much lower security of companies, which deliver their services on the other side of the border. According to the interviewed experts, the provision of services of Czech companies in Poland (and the other way round) was sometimes suspended due to the border closure. It is not clear whether these companies will be exposed to sanctions for these delays, despite they were caused by vis maior. According to the interviewed experts, this might lower the willingness of companies to take part in public procurement on the other side of the national border, which contradicts the European single market principle.

4.1.3 Border closures lowered the possibility of mutual crossborder contacts and events

The border closure disabled the organisation of joint events alongside the border. The events in the divided city Český Těšín/Cieszyn were the most affected ones: the traditional "Three Brothers' Festival", annually celebrating the memory of the founders of the town, as well as joint theatre and cinema festivals, which create a flagship of similar joint activities organised in the whole Czech-Polish borderland (Zenderowski and Krycki, 2014; Boháč, 2017), had to be cancelled or moved into virtual space.

The border closure had a negative impact in managing cross-border activities along the whole border, which are often implemented as microprojects- see subsection 4.1.6. The entire people-to-people part of the INTERREG programme has helped to organise events such as joint summer camps of Czech and Polish children. Given the pandemic-related atmosphere of fear and uncertainty, those events were the first to be cancelled.

On the other hand, the border closures and related border-crossing restrictions revealed the existence of a cross-border civic society in the east of the border, in Těšínské Slezsko/Śląsk Cieszyński Euroregion. The most visible manifestation of civic society activity was the poster event: "I miss you, neighbour". The activists placed banners on railings on their side of the border river. These posters attracted substantial media attention, and not only from the Czech Republic and Poland. Stefan Mańka, co-author of the Polish banner "I miss you, Czech" and one of the interviewed $\mathrm{CBC}$ experts, explained that he felt an urgent need to convey a positive message to lift the mood of the locals. In the same vein, the local music band Izabel reacted to the actual situation with their song Two Banks (of one river), which calls for the immediate end of border closure and has recorded a substantial number of Youtube views.

At the end of the first pandemic wave in mid-June 2020, the Czech Republic opened its borders with all neighbours, 
with one notable exception: due to the rise of the pandemic in the Polish Silesian voivodeship, the inhabitants of this region were banned from entering the Czech Republic without a quarantine for another two weeks. As this decision prolonged the separation of Cieszyn/Český Těšín, the locals from both sides of the border organised a silent protest on the border bridge to claim the return of normality - which means the open border, when Cieszyn/Český Těšín form one functional unit. This symbolic protest was led by the mayors of both towns, which underlined the meaning of the message.

\subsubsection{The pandemic contributed to the re-emergence of mutua animosities}

Despite all expressed mutual sympathies, the pandemic has also highlighted some animosities vis-à-vis the neighbour, which can still be found among the inhabitants of borderlands. The above-mentioned decision of the Czech government - initiated by the president of the MoravianSilesian Region - to restrict the entry of inhabitants of (Polish) Silesian Voivodeship into the Czech territory also after 15 June 2020, due to the high occurrence of COVID-19 cases in coal mines in this voivodeship - offered fuel for those animosities. As both concerned neighbours are partner regions and the intensity of their cooperation initiatives is high (Böhm, 2018), this decision temporarily worsened continuation of their further unproblematic cooperation.

The interviewed experts underlined their reservations and even objections against the prolongation of border closures, and some of them warned that it has damaged the outcomes of mutual cross-border initiatives and reopened mutual negative stereotypes, which were deemed to be long-forgotten (Brandys, 2020). Despite the fact that border closures were intended to be temporary, they caused major uncertainties, which stopped or at least substantially complicated the cooperation of schools. Some of them suspended all unnecessary activities, including international and cross-border cooperation and adopted the re-bordering reality quickly - and some of them even willingly. Moreover, according to the opinions of the interviewed experts, it is uncertain whether these (school) partnerships will be renewed in the post-pandemic period.

\subsubsection{Economic crisis will decrease the revenues of local actors, which could limit their ability to conduct $C B C$}

The pandemic caused the economic crisis, which will lead to decreased local and regional budgets, due to significantly lower tax revenues. Local and regional actors, who create the majority of all partners involved in CBC projects and initiatives, will moreover have to accept the strengthening of the central budget at their cost, as at least the decisions of the Czech government responding to the pandemic introduced centrally-led and implemented investments. This means that regions and municipalities will lose a substantial part of their budgetary incomes, as they have to de facto co-finance part of the COVID-19 related subsidies for entrepreneurs (Union of Czech Municipalities, 2020).

This redistribution will, according to the interviewed experts, probably exert a major negative impact also for the CBC. Municipalities and regions will have less funds at their disposal, which means that the municipalities will have to introduce austerity measures (Union of Czech Municipalities, 2020). Hence, the interviewed experts predict that all international, including cross-border cooperation, activities might be among the first victims of this expected austerity. The experts foresee that these cuts might put into question the interim cooperation achievements, which resulted from projects and long-term cross-border relationships. This can, according to these stakeholders, lead to a lower number of cross-border initiatives and a lower number of actors involved in the activities and structures of Euroregions and other cross-border entities. Some of the current cooperation stakeholders even expect that the CBC will be understood as an expendable luxury, which will only be realised in the traditional "fortresses", such as divided towns Cieszyn/Český Těšín or very close neighbours, for example Náchod-Kudowa Zdrój.

\subsubsection{The implementation of INTERREG-funded projects was substantially complicated}

All interviewed experts have been involved in managing INTERREG-funded projects. Moreover, the representatives of Euroregions are responsible for the complex management of microprojects - the subtle people-to-people initiatives of a mostly non-investment nature, encouraging the crossborder contacts. In the Czech-Polish borderland, each of six Euroregions (Nisa/Nysa, Glacensis, Praděd/Pradziad, Silesia, Těšínské Slezsko/Śląsk Cieszyński and Beskydy/ Beskidy: see Fig. 3) organises their calls for microprojects, evaluates and selects them. The $€ 45$ million for microprojects represents $20 \%$ of the INTERREG CZ-PL programme allocation (INTERREG, 2015). Microprojects have helped to organise many cultural, sporting and tourist events and provided an opportunity of meeting for the inhabitants of the borderland, as well as for tourists from outside the region (Dołzbłasz, 2013).

The border closures have negatively influenced or disabled the implementation of joint cross-border initiatives, very often co-financed from the INTERREG programme. The interviewed representatives of Euroregions, who administer the use of microprojects in their territories, underlined that the realisers of microprojects asked for modifications and prolongations of their projects under implementation, as not all of them could be done in virtual space. Moreover, they expressed their concern that the number of new microprojects will decrease in the coming years.

All other interviewed experts (those who did not represent Euroregions) implement INTERREG-funded projects. They underlined the unique position of the INTERREG programme and stressed the impossibility to implement projects, which should assist in removing the barrier function of the border, without the possibility to meet physically. This might lead to a dramatic decrease of newly prepared projects.

\subsection{The impact of border closures on cross-border cooperation roles}

In this Section we examine the above identified pandemic impacts on the five roles of CBC in the Czech-Polish borderland. We used a rating scale, where we asked the interviewed experts to sort these impacts according to their importance. A five to one scale was used, where 5 stands for the highest impact and 1 for the least impact. The goal of this section is twofold: given the ranking exercise, which CBC role was the most affected by the border closures; and we also verify whether this "five roles" concept can be used to study CBC at all.

According to the opinions of interviewed experts, presented in Table 1, the pandemic had its most serious impact on the role of $\mathrm{CBC}$ in regional development. This illustrates that the level of cross-border economic integration is rather high in the Czech-Polish borderland - which was partly 
expected in Těšínské Slezsko/Śląsk Cieszyński Euroregion, but according to the interviews and analysed texts it is also the case for the rest of the borderlands. This means that the level of cross-border integration in some parts of the "new EU" can be similarly as high as in the "old EU" and it can be - as it is for example in the German-Polish borderland considered the main co-operation engine (Jańczak, 2020).

Our research outcomes also underlined the fact that stakeholders in the Czech-Polish CBC activities consider their involvement as an integral and important part of European integration processes. The ideational level of CBC is thus important in the Czech-Polish borderland - and the interviewed experts stressed that they have attempted to underline this European integration dimension during the pandemic times.

Thus, the impact of the pandemic has been so far more serious on functional (regional development) and ideational (European integration, post-conflict reconciliation) CBC dimensions than on institutional ones. Para-diplomacy was the area where the pandemic impact was the least severe - at least in a comparative perspective, as one of the interviewed experts put it: "I think that the pandemic will, due to the lower amount of funds available for CBC, have a very negative impact on the para-diplomacy, as municipalities will have less funds to implement their projects. We can observe it already now, as the number of microprojects asking for the INTERREG financing decreased remarkably. However, the impact on European integration and crossborder economy will generally be more devastating...".

Table 1 also reveals limitations of the use of the fiveroles concept, as well as the rating scale method. These shortcomings imply that the pandemic has impacted the $\mathrm{CBC}$ in its multi-level governance role less than in its other roles, save for the case of para-diplomacy. This would be a misinterpretation, as some of the interviewed experts underlined that this multi-level governance role "overlaps with the European integration role" or "creates a substantial part".

\section{Conclusions and recommendations}

The COVID-19 pandemic has challenged EU fundamental freedoms in very complex ways (Unfried, 2020). Its consequences have been negative, mainly in the border regions (Klatt, 2020). Therefore, the main goal of this article was to assess the impacts of the COVID-19 pandemic on Czech-Polish CBC. We hypothesised that those impacts substantially complicate cooperation. We also wanted to find out whether we can expect a rise of re-bordering trends in this case study territory in a longer-term perspective.

The article should have shown whether the impact of the pandemic could be studied according to the five roles of $\mathrm{CBC}$ : 1) multi-level governance; 2 ) regional development; 3 ) paradiplomacy; 4) reconciliation; and 5) European integration. In this research project, it appeared to be a useful tool, because it helped to structure the organisation of the focus group, as five pre-defined questions/CBC roles substantially created the formulation of the impacts and consequences of the pandemic on the Czech-Polish CBC. As the concept has its limitations, mainly in the mutual overlap of the five roles, its further use should be verified in other borders and under "non-emergency" conditions.

The immediate pandemic-related re-bordering has had six principal impacts in the Czech-Polish borderland. The national governments decided to close the border and bypassed the existing cross-border governance structures. This immediately restricted cross-border flows and damaged economic development in the Czech-Polish borderland. Principally, Polish cross-border commuters and their employers (based in the Czech Republic) were impacted. The restricted border crossing lowered the number and intensity of cross-border contacts. It also contributed to the re-emergence of mutual animosities, as the act of border closures indicated that potential danger (infection) might come from the neighbours. The pandemic caused an economic crisis, which will decrease the incomes of local public actors, who could in some cases resign from CBC or restrict it. The implementation of INTERREG-funded projects was hugely complicated or disabled.

Some principal CBC stakeholders, cross-border commuters, entrepreneurs benefitting from the crossborder complementarities, also cross-border civic society, reacted actively against this re-bordering. The sudden interruption of the narrative of open borders and resignation from mutual interdependencies showed that free border crossing is considered to be a norm in the Czech-Polish borderland. The intensity of market-driven cross-border flows, based on cross-border commuting, is the main crossborder integration driver in the Czech-Polish borderland. In the east of the border, we have also observed an existing cross-border civic society, which raised its voice against rebordering strongly.

The first pandemic wave also showed that the CzechPolish borderland is very heterogeneous. Future rebordering processes are likely, but they will differ regionally. Our findings showed that Těšínské Slezsko/Śląsk Cieszyński Euroregion is the most integrated part of the borderland (as stated by Pásztó et al., 2019). It was capable of reacting to the pandemic and the high level of cross-border integration is considered to be a norm there. This was manifested by the repeated protests against the closed border, expressions of mutual sympathies vis-à-vis the neighbour led by civic society, and in the steps of the secretariat of the Euroregion, which - acting on behalf of all Polish Euroregions - helped to persuade the Polish government to ease the quarantine obligation for Polish cross-border commuters by the means of successful deliberation (Kasperek and Olszewski, 2020). In other Euroregions, cross-border labour market integration could prevent or slow down the re-bordering processes, yet the absence/low presence of existing cross-border civic society will make this task more complicated. The presence of a cross-border civic society is an important factor preventing re-bordering and is worthy of further investigation.

The pandemic will probably not impact institutional functions and the basic shape of cross-border governance bodies in the Czech-Polish borderland. Pandemic-related austerity measures, however, might restrict the ability and willingness of municipalities to participate in cross-border activities and governance structures, which might reduce the number of their members. The volume of submitted projects asking for INTERREG funding has decreased since the pandemic started. Moreover, this trend will continue, given the expected lower ability of municipalities and other actors to pre- and co-finance those projects. Hence, it might be worthwhile to re-think or to temporarily change the rules of this programme. Advance payments and/or a temporarily increased level of the financial support could help to increase the number of microprojects, and to assist in furthering this visible form of European integration in the border regions. 
The negative effects of the pandemic on the CzechPolish CBC calls for reactions of both CBC stakeholders and scholars. The principal challenge is the need to keep the borderline permeable to enhance cross-border flows. This asks for a special scenario of cooperation and also communication in emergency situations in the CzechPolish border region, which would be applied in the case of repeated border closures. Such a model could eliminate the uncertainty, which has been causing similarly serious problems as the restricted borders themselves. This is a truly multi-level challenge for local and regional CBC actors, as well as for national states and European institutions.

The existence of a border-crossing scenario in emergency situations would strengthen the understanding of the CzechPolish border region as a place for a good life (cf. Klatt, 2020). The pandemic showed that “...people living in border areas are re-shaping the European narrative of borders and especially they are the agents who make the European story through their daily life" (Medeiros et al., 2020, p. 19). This observation is valid also in the study case of the Czech-Polish borderland, given its differing intensity depending on the levels of crossborder flows. Hence, further research exploring the midand long-term influence of the pandemic on the quality of the Czech-Polish borderlands as a living place is needed. It will probably document a high heterogeneity and certain rebordering tendencies in the Czech-Polish borderland, but it could also point to examples which used the pandemic as an occasion to intensify cross-border integration.

\section{Acknowledgements}

The author wishes to thank both anonymous reviewers, who substantially helped to re-direct and improve the final version of this article. The interviewed experts offered much help and advice as well. I would like to thank Adam Pátek for his help too. This article was created from the project: SGS2020-4052, "Evaluation of the tourist potential of secondary geodiversity in northern Bohemia".

\section{References:}

BERROD, F., BRUYAS, P. (2020): European Union: are borders the antidote to the Covid-19 pandemic? [online]. The Conversation website [cit. 08.06.2020]. Available at: https://theconversation.com/european-union-areborders-the-antidote-to-the-covid-19-pandemic-136643

BOHÁČ, A. (2017): Těšín optikou geografického výzkumu rozdělených měst. ACC Journal, 13(3): 167-180.

BÖHM, H. (2020): Researching cross-border cooperation under the shadow of COVID 19 pandemic: scientific report from e-conferences and blog-reflections produced between 14 March and 21 June 2020. Pogranicze. Polish Borderlands Studies, 8(2): 81-86.

BÖHM, H. (2019): Cross-border cooperation from the perspectives of political sciences. In: Beck, J. [ed.]: Transdisciplinary Discourses on Cross-Border Cooperation in Europe (pp. 59-82). Brussels, Peter Lang.

BÖHM, H. (2018): Is Czech Para-diplomacy (Also) Eurosceptical: Example from Moravian-Silesian. Revue Roumaine de Géographie|Romanian Journal of Geography, 62(1): 71-87.

BÖHM, H., DRÁPELA, E. (2017): Cross-border Cooperation as a Reconciliation Tool: Example from the East Czech-Polish Borders. Regional and Federal Studies, 27(3): 305-319.
BÖHM, H., KUROWSKA-PYSZ, J. (2019): Can Cross-Border Healthcare Be Sustainable? An Example from the CzechAustrian Borderland, Sustainability 11(24): 1-14.

BÖHM, H., OPIOŁA, W. (2019): Czech-Polish cross-border (non)cooperation in the field of labour market: why does it seem to be un-de-bordered? Sustainability, 11(2855): 1-13.

BOUVERESSE, A. (2020): The Ambiguous Relationship between the EU and its Internal Borders: The European Citizen's Point of View. BIG Review, 1(2): 64-70.

BRANDYS, S. (2020): Juz zabraklo slów, by skomentować, to co sie dzieje [online]. Glos Ludu website [cit. 19.06.2020]. Available at: https://glos.live/KORONAWIRUS/detail/ Juz_zabraklo_slow_by_skomentowac_to_co_sie_dzieje_ Cichy_protest_nad_Olza/0

BRUNET-JAILLY, E. (2005): Theorizing borders: An interdisciplinary perspective. Geopolitics, 10(4): 633-649.

BRUNET-JAILLY, E., VALLET, E. (2020): Global talks border [online]. COVID-19 and Border website [cit. 22.04.2020]. Available at: https://ca.bbcollab.com/collab/ ui/session/playback

CALZADA, I. (2020): Will Covid-19 be the end of the global citizen [online]. Apolitical website [cit. 22.04.2020]. Available at: https://apolitical.co/en/solution_article/willCovid-19-be-the-end-of-the-global-citizen

CASTAN PINOS, J., RADIL, S. (2020): The Covid-19 pandemic has shattered the myth of a borderless Europe [online]. Blog LSE website. [cit. 12.06.2020]. Available at: https://blogs. lse.ac.uk/europpblog/2020/06/12/the-Covid-19-pandemichas-shattered-the-myth-of-a-borderless-europe/?fbcli d=IwAR1rmN8cGjoqUZlA_u3PAR2tx1yVroizTw3iV_ xHknIKoaR9QM_na45iyh0

CASELla COLEMBEAU, S. (2020): Crisis of Schengen? The effect of two 'migrant crises' (2011 and 2015) on the free movement of people at an internal Schengen border. Journal of Ethnic and Migration Studies, 46(11): 2258-2274.

CUSTRED, G. (2011): The linguistic Consequences of Boundaries, Borderlands, and Frontiers. Journal of Borderland Studies, 26(3): 265-278.

CZEPIL, B., OPIOłA, W. (2013): O znaczeniu kategorii pogranicza w polskiej politologii. Pogranicze. Polish Borderlands Studies, 1(1): 58-63.

DECOVILLE, A., DURAND, F., SOHN, C., WALTHER, O. (2013): Comparing Cross-border Metropolitan Integration in Europe: Towards a Functional Typology. Journal of Borderland Studies, 28(2): 221-237.

DOŁZBŁASZ, S. (2013): Cross-border co-operation in the Euroregions at the Polish-Czech and Polish-Slovak borders, European Countryside, 5(2): 102-114.

DOŁZBŁASZ, S. (2015): Symmetry or asymmetry? Crossborder openness of service providers in Polish-Czech and Polish-German border towns. Moravian Geographical Reports, 23(1): 2-12.

DOŁZBŁASZ S. (2017): From Divided to Shared Spaces: Transborder Tourism in the Polish-Czech Borderlands. In: Hall, D. [ed.]: Tourism and geopolitics: issues and concepts from Central and Eastern Europe (pp. 163177). Boston, CABI.

DRÁPELA, E., BAŠTA, J. (2018): Quantifying the Power of Border Effect on Liberec Region Borders. In: Dubcová, A. 
[ed.]: Geografické informácie 22 (pp. 51-60). Nitra, Constantine the Philosopher University.

DUCHACEK, I. D. (1990): Perforated Sovereignties: Towards a Typology of New Actors in International Relations. In: Michelmann, H. J., Soldatos, P. [eds.]: Federalism and International Relations. The Role of Subnational Units (pp. 1-33). Oxford, Clarendon Press.

DURA, A., CAMONITA, F., BERZI, M., NOFERINI, A. (2019): Euroregions, Excellence and Innovation across EU borders. A Catalogue of Good Practices. Barcelona, Department of Geography.

ESPINOZA, B., CASTILLO-CHAVEZ, C., PERRINGS, C. (2020): Mobility restrictions for the control of epidemics: When do they work? PLoS ONE, 15(7): 1-14.

ESPON (2018): Crossborder Public Services - Final ReportPractical Guide for Developing Cross-border Public Services [online]. ESPON website [cit. 20.09.2020]. Available at: https://www.espon.eu/CPS

EURONEWS (2020): COVID-19 has 'weakened' the case for the EU, say Germans, French and Italians. Available at: https://www.euronews.com/2020/05/26/Covid-19-hasweakened-the-case-for-the-eu-say-germans-french-anditalians

FALUDI, A. [ed.] (2018): The Poverty of Territorialism. A Neo-Medieval View of Europe and European Planning. Cheltenham, Edward Elgar.

FURMANKIEWICZ, M. (2007): International Cooperation of Polish Municipalities: Directions and Effects. Tijdschrift voor Economische en Sociale Geografie, 98(3): 349-359.

FURMANKIEWICZ, M., BURYŁO, K., DOŁZBŁASZ, S. (2020): From service areas to empty transport corridors? The impact of border openings on service and retail facilities at Polish-Czech border crossings. Moravian Geographical Reports, 28(2): 136-151.

HAVLÍČEK, T., JEŘÁBEK, M., DOKOUPIL, J. [eds.] (2018): Borders in Central Europe after Schengen Agreement. Cham, Springer Verlag.

HETMAN, A. (2020): Jak pomóc pracującym w Czechach? Prezydent Anna Hetman apeluje do premiera [online]. Jastrzebie-Zdrój website. [cit. 02.12. 2020]. Available at: https://www.jastrzebie.pl/strefa-mieszkanca/aktualnosci/ aktualnosc/jak-pomoc-pracujacym-w-czechachprezydent-anna-hetman-apeluje-do-premiera/

HOOGHE, L., MARKS, G. (2003): Unravelling the Central State, but how? Types of Multi-Level Governance, American Political Science Review, 97(2): 233-243.

INTERREG CZ-PL VA (2015): Podstawowe Informacje o Programie [online]. Interreg Programme website. [cit. 16.06. 2020]. Available at: http://pl.cz-pl.eu/zakladniinformace-o-programu-pl

JAANSOO, A. (2019): Provision of Services across International Borders: Factors Driving Cooperation of Subnational Governments in Europe. Dissertation thesis.

JAŃCZAK, J. (2014): Borders and border dimensions in Europe. Between frontierisation and boundarisation. Public Policy and Economic Development, 14(2): 7-18.

JAŃCZAK, J. (2020): The German-Polish border, rebordering and the pandemic: centers vs. peripheries? [online]. Borders in Motion website. [cit. 16.06. 2020]. Available at: https://bordersinmotion-coronablog. com/2020/06/09/the-german-polish-border-re-borderingand-the-pandemic-centers-vs-peripheries/

KASPEREK, B., OLSZEWSKI, M. (2020): Społecznogospodarcze skutki zamknięcia polsko-czeskiej granicy dla pracowników transgranicznych w Euroregionie Śląsk Cieszyński w związku z pandemią COVID-19 [online]. Olza Association website. [cit. 04.05.2020]. Available at: http://www.olza.pl/pl/pliki-do-pobrania/

KEATING, M. (1998): The new regionalism in Western Europe: Territorial restructuring and political change. Cheltenham, Edward Elgar.

KLATT, M. (2018): The So-Called 2015 Migration Crisis and Euroscepticism in Border Regions: Facing Re-Bordering Trends in the Danish-German Borderlands, Geopolitics 25(3): 567-586.

KLATT, M. (2020): What has happened to our cross-border regions? Corona, Unfamiliarity and transnational borderlander activism in the Danish-German border region [online]. University of the Greater Region website. [cit. 20.06.2020]. Available at: http://cbs.uni-gr. eu/en/resources/borderobs

KLATT, M., WASSENBERG, B. (2017): Introduction: Secondary Foreign Policy: Can Local and Regional Cross Border Cooperation Function as a Tool for PeaceBuilding and Reconciliation? Regional and Federal Studies, 27(3): 205-218.

KRIPPENDORFF, K. (2004): Content Analysis: An Introduction to its Methodology. Thousand Oaks, Sage.

KROSNICK, J.A., PRESSER, S. (2010): Question and Questionnaire Design. In: Marsden, P. V., Wright, J. D. [eds.]: Handbook of Survey Research (pp. 263-313). Bingley, Emerald Group Publishing Limited.

MEDEIROS, E., RAMÍRÉZ, M. G., OCSKAY, G., PEYRONY, J. (2020): Covidfencing effects on cross-border deterritorialism: the case of Europe, European Planning Studies (online first). DOI: 10.1080/09654313.2020.1818185.

NATIONAL PANDEMIC ALARM (2020): Research of 16 April 2020 [online]. National Pandemic Alarm website. [cit. 20.04. 2020]. Available at: www.nationalpandemicalarm.eu

NEUENDORF, K. A. [ed.] (2017): The Content Analysis Guidebook. Second Edition. Thousand Oaks, Sage.

NOVINKY.CZ (2020): Některým firmám chybějí polští pendleři [online]. Novinky.cz website. [cit. 20.04. 2020]. Available at: https://www.novinky.cz/domaci/clanek/ nekterym-firmam-chybeji-polsti-pendleri-40318545

OFFICIAL JOURNAL OF THE EUROPEAN UNION (2008): Consolidated versions of the Treaty on European Union and the Treaty on the Functioning of the European Union [online]. European Union website. [cit. 15.06.2020]. Available at: https://eur-lex.europa.eu/legalcontent/EN/TXT/?uri=OJ:C:2008:115:TOC

OFFICIAL JOURNAL OF THE EUROPEAN UNION (2004): Directive 2004/38/EC of the European Parliament and of the Council of 29 April 2004 on the right of citizens of the Union and their family members to move and reside freely within the territory of the Member States [online]. European Union website. [cit. 15.06.2020]. Available at: https://eur-lex.europa.eu/legal-content/EN/ TXT/?uri $=$ celex\%3A32004L0038 
OPIŁOWSKA, E. (2020): The Covid-19 crisis: the end of a borderless Europe? European Societies, 23(S1): S589S600.

PÁSZTÓ, V., MACKU゚, K., BURIAN, J., PÁNEK, J., TUČEK, P. (2019): Capturing cross-border continuity: The case of the Czech-Polish borderland. Moravian Geographical Reports, 27(2): 122-138.

PERKMANN, M. (2003): Cross-Border Regions in Europe: Significance and Drivers of Regional Cross-Border Cooperation. European Urban and Regional Studies, 10(2): 153-171.

PTÁČEK, P., KLADIVO, P., ROUBÍNEK, P., SIWEK, T., ZIENER, K. (2017): Granica w świadomości i w rzeczywistości: dwa przykłady $\mathrm{z}$ nowych krajów członkowskich Unii Europejskiej. Studia Socjologiczne, 224(1): 167-193.

RIEDEL, R. (2018): Great Britain and differentiated integration in Europe. In: Chochia, A., Kerikmäe, T., Ramiro Troitino, D. [eds.]: Brexit: History, Reasoning and Perspectives (pp. 99-112). Cham, Springer International.

RUFÍ, J. V., RICHARD, Y., FELIU, J., BERZI, M. (2020): Editorial: Peripheral borders, soft and hard re-bordering in Europe [online]. Belgeo journal website. [cit. 12.06.2020]. Available at: http://journals.openedition. org/belgeo/37391

SCOTT, J.W. (1999): European and North American Contexts for Cross-border Regionalism. Regional Studies, 33(7): 605-617.

SCOTT, J. W. (2019): Border Regions. In: Orum, M. A. [ed.]: The Wiley Blackwell Encyclopedia of Urban and Regional Studies (pp. 149-153). Chichester, Wiley Blackwell.

SCHWARZ, T. (2020): Germany to partially close borders with neighbours [online]. POLITICO website. [cit. 14.06.2020]. Available at: https://www.politico.eu/article/ germany-to-partially-close-borders-with-neighbors

SCUZZARELLO, S., KINNVALL, C. (2012): Rebordering France and Denmark narratives and practices of borderconstruction in two European Countries. Mobilities 8(1): 90-106.

SDRUŽENÍ MÍSTNÍCH SAMOSPRÁV ČR (2020): Obce kvůli vládním škrtům ruší investice [online]. Union of Czech Municipalities website. [cit. 02.06.2020]. Available at: https://www.smscr.cz/cz/62-aktuality/2349-obce-kvulivladnim-skrtum-rusi-investice

SIWEK, T. (2018): Silesian Identity across the Internal Border of the EU. In: Borders in Central Europe after the Schengen Agreement (pp. 167-177). Cham, Springer.
STOKLOSA, K., BESIER, G. (2014): Introduction: Some thoughts regarding the study of borders and border regions. In: Stoklosa, K., Besier, G. [eds.]: European Border Regions in Comparison. Overcoming Nationalistic Aspects or Re-Nationalization? (pp. 1-16). New York, Routledge.

SVENSSON, S. (2020): Resistance or Acceptance? The Voice of Local Cross-Border Organizations in Times of ReBordering, Journal of Borderlands Studies (online first). Doi: 10.1080/08865655.2020.1787190.

TELO, M. (2007): European Union and New Regionalism. Farnham, Ashgate.

UHER, J. (2018): Quantitative Data From Rating Scales: An Epistemological and Methodological Enquiry. Frontiers in Psychology, 9(2599): 1-27.

UNFRIED, M. (2020): Cross-border governance in times of crisis, First experiences from the Euroregion MeuseRhine. The Journal of Cross Border Studies in Ireland, 15(1): 87-97.

VAISHAR, A., DVOŘÁK, P., HUBAČÍKOVÁ, V., ZAPLETALOVÁ, J. (2013): Contemporary development of peripheral parts of the Czech-Polish borderland: Case study of the Javorník area. Geographia Polonica, 86(3): 237-253.

VAN DER VELDE, M., SPIERINGS, B. (2010): Consumer Mobility and the Communication of Difference: Reflecting on Cross-Border Shopping Practices and Experiences in the Dutch-German Borderland. Journal of Borderlands Studies, 25(3-4): 191-205.

VAN HOUTUM, H., VAN DER VELDE, M. (2004): The power of cross-border labour market immobility. Tijdschrift voor economische en sociale geographie. 95(2): 100-107.

WALTERS, W. (2004): The Frontiers of the European Union: A Geostrategic Perspective. Geopolitics, 9(3): 674-698.

WARLEIGH-LACK, A., ROBINSON, N., ROSAMOND, B. (2011): New Regionalism and the European Union. Dialogues, comparisons and new research directions. New York, Routledge.

WASSENBERG, B. (2020): The Schengen Crisis and the End of the Myth of "Europe without Borders". BIG Review, $1(2): 30-39$.

ZENDEROWSKI, R.; KRYCKI M. (2014): Public diplomacy w miastach podzielonych granicą państwową. Przykład Cieszyna i Czeskiego Cieszyna. Pogranicze - Polish Borderland Studies 2(2): 206-227.

ZUMBUSCH, K., SCHERER, R. (2019): Cross-border cooperation and political science. In: Beck, J. [ed.]: Transdisciplinary Discourses on Cross-Border Cooperation in Europe (pp. 29-58). Brussels, Peter Lang.

\section{Please cite this article as:}

BÖHM, H. (2021): The influence of the Covid-19 pandemic on Czech-Polish cross-border cooperation: From debordering to re-bordering? Moravian Geographical Reports, 29(2): 137-148. doi: https://doi.org/10.2478/mgr-2021-0007 